\title{
Description of Thermoanaerobacter brockii subsp. lactiethylicus subsp. nov., Isolated from a Deep Subsurface French Oil Well, a Proposal To Reclassify Thermoanaerobacter finnii as Thermoanaerobacter brockii subsp. finnii comb. nov., and an Emended Description of Thermoanaerobacter brockii
}

\author{
J.-L. CAYOL, ${ }^{1}$ B. OLLIVIER, ${ }^{1 *}$ B. K. C. PATEL,${ }^{1,2}$ G. RAVOT, ${ }^{1}$ M. MAGOT, ${ }^{3}$ \\ E. AGERON ${ }^{4}$ P. A. D. GRIMONT, ${ }^{4}$ AND J.-L. GARCIA ${ }^{1}$ \\ Laboratoire de Microbiologie ORSTOM, Université de Provence, 13331 Marseille Cedex $3,{ }^{1}$ Sanofi Recherche, \\ Centre de Labège, 31676 Labège Cedex, ${ }^{3}$ and Unité des Entérobactéries, Institut Pasteur, \\ 75724 Paris Cedex 15, ${ }^{4}$ France, and Faculty of Science and Technology, \\ Griffith University, Nathan, Brisbane, 4111 Australia $^{2}$
}

\begin{abstract}
A strictly anaerobic, thermophilic, gram-positive, spore-forming eubacterium designated strain SEBR 5268 ${ }^{\mathrm{T}}$ $\left(\mathrm{T}=\right.$ type strain) was isolated from an oil field at a depth of $2,100 \mathrm{~m}$, where the temperature was $92^{\circ} \mathrm{C}$. The cells of this organism were gram-positive, straight, motile rods $(0.5$ by 2 to $3 \mu \mathrm{m})$ with peritrichous flagella. The cells occurred singly or in pairs during the logarithmic growth phase, but were pleomorphic and filamentous (length, $15 \mu \mathrm{m}$ ) in old cultures. Growth occurred at temperatures of 40 to $75^{\circ} \mathrm{C}$, and optimum growth occurred at temperatures between 55 and $60^{\circ} \mathrm{C}$. The fermentable substrates included glucose, fructose, galactose, mannose, cellobiose, maltose, sucrose, lactose, D-xylose, D-ribose, mannitol, pyruvate, and starch. The products of fermentation of glucose were lactate, acetate, ethanol, $\mathrm{H}_{2}$, and $\mathrm{CO}_{2}$. The DNA base composition was $35 \mathrm{~mol} \% \mathrm{G}+\mathrm{C}$. The results of $16 \mathrm{~S}$ rRNA sequence comparisons indicated that strain SEBR $5268^{\mathrm{T}}$ was closely related to Thermoanaerobacter brockii and Thermoanaerobacter finnii, and these three organisms exhibited levels of ribosomal DNA sequence homology of 98 to $99 \%$. The results of DNA-DNA hybridization studies performed with the three organisms confirmed this close affiliation, and as base pairing values of $>70 \%$ were obtained, these organisms belong to the same species. Therefore, we propose that $T$. finnii should be reclassified as a subspecies of $T$. brockii, Thermoanaerobacter brockii subsp. finnii comb. nov. This automatically creates Thermoanaerobacter brockii subsp. brockii. We also propose that strain SEBR $5268^{\mathrm{T}}$ should be classified as a member of a new subspecies of $T$. brockii, Thermoanaerobacter brockii subsp. lactiethylicus. The latter differs from $T$. brockii subsp. brockii and $T$. brockii subsp. finnii by its $16 \mathrm{~S}$ rRNA sequence, DNA sequence diversity, lower temperature optimum, $\mathrm{G}+\mathrm{C}$ content, and carbohydrate utilization spectrum. Strain SEBR $\mathbf{5 2 6 8}^{\mathrm{T}}$ has been deposited in the Deutsche Sammlung von Mikroorganismen as strain DSM 9801 $^{\mathrm{T}}$.
\end{abstract}

In the past two decades, workers have performed intensive studies to isolate thermophilic, anaerobic, carbohydrate-fermenting eubacteria from marine and terrestrial volcanic hot springs $(24,41)$, and have studied these organisms with a view toward using these microbes and their enzymes for biotechnological applications (24). Because of the large number of new isolates, the taxonomy of this group of bacteria has been revised recently, mainly on the basis of $16 \mathrm{~S}$ rRNA sequence data (9).

Oil fields represent a new and exciting ecosystem because of their physicochemical conditions. Some oil-bearing reservoirs are deep seated and include halophilic and thermal environments which are conducive to the growth of thermophilic bacteria. To date, only a few reports describing thermophilic bacteria obtained from such environments have been published, and the strains described include methanogens $(11,18,29)$, sulfate reducers $(8,28)$, elemental sulfur reducers $(37)$, and fermentative bacteria $(12,30,33)$. During microbiological in-

* Corresponding author. Mailing address: Laboratoire de Microbiologie ORSTOM, Université de Provence, Case 87, 3 Place Victor Hugo, 13331 Marseille Cedex 3, France. Phone: 33-91-10-64-80. Fax: 33-91-10-64-81. Electronic mail address: rogerpa@loma.orstom.fr. vestigations of oil fields, we isolated several fermentative thermophilic strains that belong to the genus Thermoanaerobacter and are capable of using thiosulfate as an electron acceptor in the presence of $\mathrm{H}_{2}$, amino acids, peptides, or carbohydrates (12-14). In this paper we describe the isolation, characterization, and distribution of thermophilic, anaerobic, fermentative bacteria belonging to the genus Thermoanaerobacter obtained from oil fields.

\section{MATERIALS AND METHODS}

Origins of strains. Strain SEBR $5268^{\mathrm{T}}$ ( $\mathrm{T}=$ type strain) was isolated from a French oil field, whereas strains SEBR 7311 and SEBR 7312 were isolated from African oil fields in Cameroon. The in situ temperature of the wells was $92^{\circ} \mathrm{C}$, but the temperatures were 51 to $53^{\circ} \mathrm{C}$ by the time that the samples were collected at the wellhead. The method of sampling used has been described elsewhere (3). Thermoanaerobacter finnii AKO-1 ${ }^{\mathbf{T}}$ (= DSM 3389) and Thermoanaerobacter brockii $\mathrm{HTD}^{\mathrm{T}}$ (= DSM $1457^{\mathrm{T}}$ ) were obtained from the Deutsche Sammlung von Mikroorganismen, Braunschweig, Germany. All strains were routinely cultured in the glucose-based growth medium described below.

Culture medium. A glucose-based medium was used to culture the strains. This medium contained (per liter) $1.0 \mathrm{~g}$ of $\mathrm{NH}_{4} \mathrm{Cl}, 0.3 \mathrm{~g}$ of $\mathrm{K}_{2} \mathrm{HPO}_{4}, 0.3 \mathrm{~g}$ of $\mathrm{KH}_{2} \mathrm{PO}_{4}, 1.3 \mathrm{~g}$ of $\mathrm{MgCl}_{2} \cdot 6 \mathrm{H}_{2} \mathrm{O}, 0.1 \mathrm{~g}$ of $\mathrm{CaCl}_{2} \cdot 2 \mathrm{H}_{2} \mathrm{O}, 2.0 \mathrm{~g}$ of KCl, $2.0 \mathrm{~g}$ of $\mathrm{NaCl}, 0.5 \mathrm{~g}$ of $\mathrm{CH}_{3} \mathrm{COONa}, 5.0 \mathrm{~g}$ of bio-Trypcase (bioMerieux, Craponne, France), $5.0 \mathrm{~g}$ of yeast extract (Difco Laboratories, Detroit, Mich.), $10.0 \mathrm{~g}$ of glucose, $1 \mathrm{ml}$ of $0.1 \%$ resazurin, and $10 \mathrm{ml}$ of a trace element solution (1). Unless indicated otherwise, the anaerobic technique of Hungate was used throughout 
this study $(17,25,27)$. Portions $(20 \mathrm{ml})$ of the anaerobic medium were dispensed into $50-\mathrm{ml}$ serum bottles under a stream of oxygen-free $\mathrm{N}_{2}-\mathrm{CO}_{2}(80: 20)$. The medium dispensed in this way was sterilized for $45 \mathrm{~min}$ at $110^{\circ} \mathrm{C}$. Just prior to inoculation, $0.2 \mathrm{ml}$ of $2 \% \mathrm{Na}_{2} \mathrm{~S} \cdot 9 \mathrm{H}_{2} \mathrm{O}, 1 \mathrm{ml}$ of $10 \% \mathrm{NaHCO}_{3}, 0.2 \mathrm{ml}$ of a vitamin solution (31), and $0.1 \mathrm{ml}$ of a $0.2 \%$ sodium dithionite solution (from sterilized anaerobic stock solutions) were injected into each bottle. For enrichment cultures $2 \mathrm{ml}$ of a sample was injected, and the preparation was incubated at $60^{\circ} \mathrm{C}$ for $24 \mathrm{~h}$ without shaking. Pure cultures were obtained by repeatedly using the agar shake dilution method with glucose-based medium that was supplemented with $2 \%$ Noble agar.

Nutritional characterization. Basal medium containing $1 \mathrm{~g}$ of yeast extract per liter and $1 \mathrm{~g}$ of bio-Trypcase per liter but no glucose was used for nutritiona characterization. This medium was prepared as described above, and $5-\mathrm{ml}$ portions were distributed into Hungate tubes. Just prior to inoculation, $0.05 \mathrm{ml}$ of a $2 \% \mathrm{Na}_{2} \mathrm{~S} \cdot 9 \mathrm{H}_{2} \mathrm{O}$ sterile anaerobic stock solution and $0.25 \mathrm{ml}$ of a $10 \% \mathrm{NaHCO}_{3}$ sterile anaerobic stock solution were injected into each tube. Substrates were injected from sterile anaerobic stock solutions to give final concentrations of 20 $\mathrm{mM}$, unless indicated otherwise.

pH, temperature, and sodium chloride ranges for growth. In the $\mathrm{pH}$ studies, prereduced growth medium in anaerobic tubes was adjusted to the desired $\mathrm{pH}$ with $\mathrm{NaHCO}_{3}$ or $\mathrm{Na}_{2} \mathrm{CO}_{3}$ sterile anaerobic stock solutions. In the salt range studies, sodium chloride was weighed directly in tubes to give the desired final concentrations, and then the basal glucose medium was dispensed into these tubes as described above. Basal glucose medium containing the optimum sodium chloride concentration and the optimum $\mathrm{pH}$ were used in the temperature range studies.

Analytical techniques. Volatile fatty acids and alcohols were analyzed as described previously (7). Bacterial growth was monitored by measuring the optical density at $660 \mathrm{~nm}$ with a model UV-160A spectrophotometer (Shimadzu Corp., Kyoto, Japan). DNA was isolated from exponentially growing cells, and the guanine-plus-cytosine $(\mathrm{G}+\mathrm{C})$ content was determined by using high-performance liquid chromatography as described previously $(6,26)$. Phase-contrast microscopy was performed as described previously (7).

16S rRNA sequence studies. Semipurified DNA was extracted for amplification of the $16 \mathrm{~S}$ rRNA gene by using the following protocol. A $20-\mathrm{ml}$ culture was centrifuged, and the resulting pellet was resuspended in $50 \mu \mathrm{l}$ of lysis buffer ( 50 $\mathrm{mM}$ Tris- $\mathrm{HCl}$ [pH 7.2], $50 \mathrm{mM}$ EDTA, 3\% sodium dodecyl sulfate) and transferred into a microcentrifuge tube with a pipette. The suspension was microwaved at the high power setting for four cycles, each of which consisted of 15 with the heat on and $5 \mathrm{~s}$ with the heat off with the lid of the tube open. Then 350 $\mu l$ of lysis buffer was added, the lid was closed, the preparation was incubated a $80^{\circ} \mathrm{C}$ for $15 \mathrm{~min}$, and the suspension was vortexed with $400 \mu \mathrm{l}$ of phenolchloroform (1:1). The preparation was then centrifuged at $13,000 \times g$ for $15 \mathrm{~min}$ to separate the phases. The top aqueous phase (approximately $200 \mu \mathrm{l}$ ) was removed; we were careful to avoid any material from the interface when we did this. Then $10 \mu \mathrm{l}$ of isopropanol and $5 \mu \mathrm{l}$ of $5 \mathrm{M}$ sodium acetate $(\mathrm{pH} 5.8)$ were added to the aqueous phase, and the preparation was vortexed. The suspension was centrifuged at $13,000 \times g$, and the resulting pellet was washed with cold $80 \%$ ethanol, placed in a desiccator to evaporate the residual ethanol, resuspended in $50 \mu \mathrm{l}$ of sterile distilled water, and stored at $-20^{\circ} \mathrm{C}$ until it was used. Amplification of the 16S rRNA gene from the semipurified DNA followed by purification of the amplified product was performed as described previously $(23,34)$. The purified PCR product was sequenced directly with an ABI automated DNA sequencer by using a Prism dideoxy terminator cycle sequencing kit and the protocols recommended by the manufacturer (Applied Biosystems, Ltd., Foster City, Calif.). The primers used for sequencing have been described previously (34)

The ae 2 editor was used to align the $16 \mathrm{~S}$ ribosomal DNA sequence obtained from the sequencing data with the sequences of various members of the bacterial phylum obtained from the Ribosomal Database Project (version 4.0) (21). Positions of sequence and alignment uncertainty were omitted from the analysis, and pairwise evolutionary distances based on 1,320 unambiguous nucleotides were computed by using the method of Jukes and Cantor (19). Dendrograms were constructed from evolutionary distances by using the neighbor-joining method, a transversion analysis was performed by using the program DNAPARS and tree topology was examined by using 100 bootstrapped data sets by running the script file DBOOT. For DBOOT we used the following sequence of events during the analysis: SEQBOOT, DNADIST, FITCH, and CONSENSE. Al programs are available as part of the PHYLIP package (15). Programs available in the Molecular Evolutionary Genetic Analysis (MEGA) package, version 1 (20), were also used in the analysis. All of the programs except the MEGA programs were run on a Sun Sparc workstation; the MEGA programs were run on a Toshiba model T3100SX 386 laptop IBM-compatible computer.

DNA relatedness. DNA was extracted and purified as described elsewhere (5). The exact procedures used for in vitro labelling of DNA with tritium-labelled nucleotides and for hybridization experiments ( $\mathrm{S} 1$ nuclease-trichloroacetic acid procedure) have been described previously (16). The temperature at which $50 \%$ of the reassociated DNA became hydrolyzable by the $\mathrm{S} 1$ nuclease $\left(T_{m}\right)$ was determined as described by Crosa et al. (10). The difference between the $T_{m}$ of a homoduplex and the $T_{m}$ of a heteroduplex $\left(\Delta T_{m}\right)$ provided an estimate of the level of divergence between two DNAs (4).
Nucleotide sequence accession number. The $16 \mathrm{~S}$ rRNA sequence of strain SEBR $5268^{\mathrm{T}}$ has been deposited in the GenBank data library under accession number U14330.

\section{RESULTS}

Enrichment and isolation. After incubation at $60^{\circ} \mathrm{C}$ for $48 \mathrm{~h}$, three enrichment cultures were found to be positive for growth. Microscopic examination revealed bacterial populations composed of nonsporulating rods. Enrichment cultures were maintained by repeatedly transferring $1 \%$ inocula into fresh anaerobic glucose-based medium. Colonies (diameter, 4 $\mathrm{mm}$ ) developed in the roll tubes after incubation at $60^{\circ} \mathrm{C}$ for $48 \mathrm{~h}$. All of the colonies were smooth, uniformly round, mucoid, nonpigmented, and flat, indicating that the populations were homogeneous. Three strains that were very similar to each other were isolated and were designated strains SEBR $5268^{\mathrm{T}}$, SEBR 7311, and SEBR 7312. SEBR $5268^{\mathrm{T}}$ was obtained from enrichment cultures that had been grown under an $\mathrm{N}_{2}-\mathrm{CO}_{2}$ (80:20) gas phase, whereas strains SEBR 7311 and SEBR 7312 were obtained from enrichment cultures in modified basal medium containing $1 \% \mathrm{NaCl}$ and $20 \mathrm{mM}$ thiosulfate with $\mathrm{H}_{2}-\mathrm{CO}_{2}\left(2 \times 10^{5} \mathrm{~Pa}\right)$ as the gas phase. Only limited genotypic studies were performed with strains SEBR 7311 and SEBR 7312, whereas strain SEBR $5268^{\mathrm{T}}$ was studied in greater detail.

Cellular features. Cells of strain SEBR $5268^{\mathrm{T}}$ were straight rods (Fig. 1) that were $0.5 \mu \mathrm{m}$ in diameter and 2 to $3 \mu \mathrm{m}$ long during the exponential growth phase. They occurred singly and in pairs in young cultures. However, pleomorphic forms, including filaments up to $15 \mu \mathrm{m}$ long, developed in old cultures. Strain SEBR $5268^{\mathrm{T}}$ was motile and possessed peritrichous flagella (data not shown). Spores were never observed on rich medium containing glucose and in the presence of thiosulfate, but were observed after $48 \mathrm{~h}$ of incubation at $60^{\circ} \mathrm{C}$ (Fig. 1) in a medium containing D-xylose and thiosulfate. In addition, growth was observed after the culture was pasteurized at $90^{\circ} \mathrm{C}$ for $20 \mathrm{~min}$ on glucose-thiosulfate medium. Cells from all phases of growth were gram positive. Electron microscopy also revealed a gram-positive type of cell wall (data not shown)

Growth and nutritional properties. Strain SEBR $5268^{\mathrm{T}}$ required yeast extract to ferment carbohydrates. The doubling time of this isolate in glucose medium was about $2 \mathrm{~h}$ at $60^{\circ} \mathrm{C}$. The relationship between strain SEBR $5268^{\mathrm{T}}$ growth and temperature is shown in Fig. 2. The optimum temperature for growth was between 55 and $60^{\circ} \mathrm{C}$. Strain SEBR $5268^{\mathrm{T}}$ did not grow at 37 or $80^{\circ} \mathrm{C}$. Growth occurred in the presence of $\mathrm{NaCl}$ concentrations up to $4.5 \%$. Growth was detected at $\mathrm{pH}$ values between 5.6 and 8.8. The energy sources used by strain SEBR $5268^{\mathrm{T}}$ were glucose, fructose, galactose, mannose, cellobiose, maltose, sucrose, lactose, D-xylose, D-ribose, mannitol, pyruvate, starch, and yeast extract, but no growth was observed on L-arabinose, cellulose, L-rhamnose, glycerol, ribitol, galactitol, sorbose, or melibiose. The fermentation products during growth on glucose were lactate, acetate, ethanol, $\mathrm{H}_{2}$, and $\mathrm{CO}_{2}$. Strain SEBR $5268^{\mathrm{T}}$ did not grow on cellulose and did not grow by reducing sulfate, nitrate, or fumarate. Thiosulfate, sulfite, and elemental sulfur were reduced to sulfide.

DNA base composition. The DNA base composition of strain SEBR $5268^{\mathrm{T}}$ was $35 \mathrm{~mol} \% \mathrm{G}+\mathrm{C}$.

16S rRNA sequence analysis. Comparisons of partial $16 \mathrm{~S}$ rRNA gene sequences (500 nucleotides) revealed that strains SEBR 5268 ${ }^{\mathrm{T}}$, SEBR 7311, and SEBR 7312 were closely related as they exhibited a level of sequence similarity of $99 \%$ (data not shown). Therefore, the complete sequence of only strain SEBR $5268^{\mathrm{T}}$ (1,507 bases) was determined. This sequence 


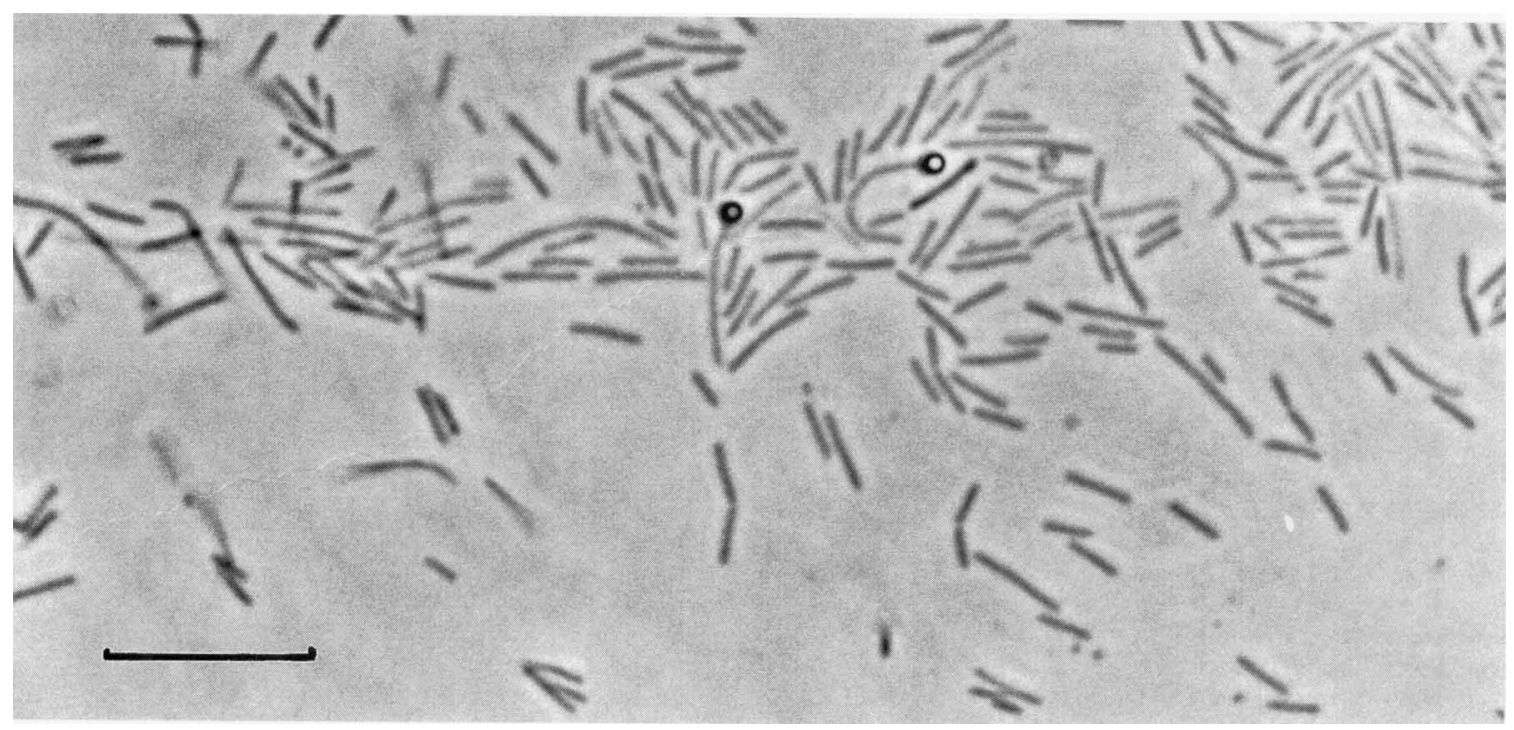

FIG. 1. Phase-contrast photomicrograph of strain SEBR $5268^{\mathrm{T}}$ showing terminal spores. Bar $=10 \mu \mathrm{m}$.

(positions 32 to 1,541; Escherichia coli numbering of Winker and Woese [40]) was aligned with the sequences of representatives of the various phyla of the domain Bacteria, and a phylogenetic analysis was performed. This analysis revealed that strain SEBR $5268^{\mathrm{T}}$ was a member of the low-G+C-content, gram-positive phylum. Additional sequence alignment and evolutionary distance analyses performed with members of this phylum indicated that the closest relatives of strain SEBR $5268^{\mathrm{T}}$ were $T$. finnii, $T$. brockii, and strain Gluc 1 (Table 1). Isolation of strain Gluc 1 has been described, but detailed characteristics of this isolate have not been published yet (38). The 16S rRNA sequence of strain Gluc 1 was obtained from the Ribosomal Database Project (21). Figure 3 is a dendrogram which was generated by the neighbor-joining method (15) from a Jukes-Cantor evolutionary distance matrix (19) (Table 1) and shows these relationships.

DNA relatedness. Strains SEBR $5268^{\mathrm{T}}$, SEBR 7311, and SEBR 7312 were closely related to both $T$. finnii and $T$. brockii. Most of the similarity values were $>70 \%$ with a $\Delta T_{m}$ of $0^{\circ} \mathrm{C}$; the only exception was $T$. brockii and strain SEBR $7311\left(\Delta T_{m}\right.$, $1^{\circ} \mathrm{C}$ ) (Table 2).

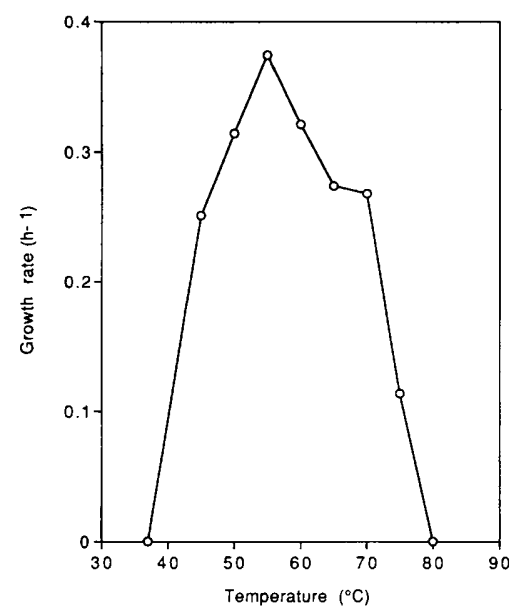

FIG. 2. Effect of temperature on the growth rate of strain SEBR $5268^{\mathrm{T}}$.

\section{DISCUSSION}

Isolation of members of various physiological groups of thermophilic bacteria from deep subsurface environments has been reported previously, and the organisms isolated include methanogens and sulfur- or sulfate-reducing bacteria $(11,28$, 37). To date, no formal characterization of fermentative bacteria isolated from such environments has been published, although short descriptions of strains SEBR $5268^{\mathrm{T}}$ and Gluc 1 have appeared previously $(12,38)$. Our formal description of strain SEBR $5268^{\mathrm{T}}$ obtained from an oil field in this paper extends the physiological diversity and taxonomic diversity of thermophiles found in deep subsurface environments.

Strain SEBR $5268^{\mathrm{T}}$ did not grow at temperatures above $75^{\circ} \mathrm{C}$, although the in situ temperature of the oil well from which it was isolated was $92^{\circ} \mathrm{C}$, indicating that this microbe may colonize the cooler parts of the reservoir. However, we cannot eliminate the possibility that thermophilic anaerobic heterotrophs may have been introduced during sample collection. Interestingly, strain SEBR $5268^{\mathrm{T}}$ cells sporulated when they were grown with D-xylose as an electron donor and thiosulfate as an electron acceptor; thus, this organism is able to survive but not necessarily grow at temperatures higher than $75^{\circ} \mathrm{C}$.

Strain SEBR $5268^{\mathrm{T}}$ has been reported to utilize thiosulfate as an electron acceptor and to produce sulfide (12). When yeast extract was used as a growth substrate, $\mathrm{H}_{2}$ was oxidized to $\mathrm{H}_{2} \mathrm{~S}$ by this isolate in the presence of thiosulfate. $\mathrm{H}_{2}$ oxidation took place mainly after the exponential growth phase. These physiological features $\left(\mathrm{H}_{2}\right.$ consumption and sulfide production) make strain SEBR $5268^{\mathrm{T}}$ a potential biocorrosive agent in oil petroleum fields in the presence of thiosulfate (12-14). The diversity and role in pipeline corrosion and biofouling of fermentative bacteria similar to strain SEBR $5268^{\mathrm{T}}$ are currently being examined by workers in our laboratories.

Strain SEBR $5268^{\mathrm{T}}$ is a sporulating, anaerobic, rod-shaped thermophile which ferments a variety of sugars and produces ethanol, acetate, lactate, $\mathrm{CO}_{2}$, and $\mathrm{H}_{2}$. In this respect strain SEBR $5268^{\mathrm{T}}$ is similar to numerous thermoanaerobes belonging to the domain Bacteria. However, phylogenetically, strain SEBR $5268^{\mathrm{T}}$ is clearly related to Thermoanaerobacter species, including $T$. finnii and $T$. brockii (average level of similarity, 
TABLE 1. Evolutionary distance matrix determined from a comparison of the 16S rRNA sequences of carbohydrate-fermenting thermoanaerobes by using the method of Jukes and Cantor ${ }^{a}$

\begin{tabular}{|c|c|c|c|c|c|c|c|c|c|c|c|c|c|}
\hline \multirow[b]{2}{*}{ Strain } & \multicolumn{13}{|c|}{ Evolutionary distance } \\
\hline & 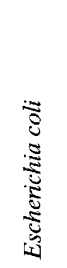 & 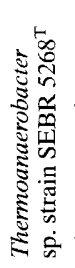 & 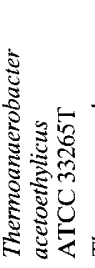 & 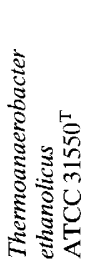 & 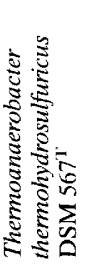 & 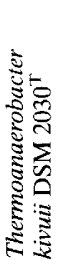 & 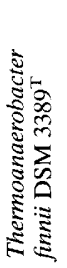 & 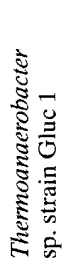 & 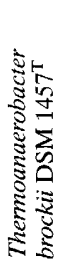 & 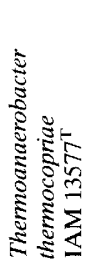 & 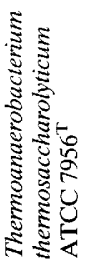 & 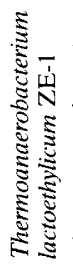 & 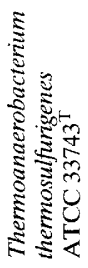 \\
\hline Thermoanaerobacter sp. strain SEBR $5268^{\mathrm{T}}$ & 27.6 & & & & & & & & & & & & \\
\hline Thermoanaerobacter acetoethylicus ATCC $33265 \mathrm{~T}$ & 28.4 & 4.0 & & & & & & & & & & & \\
\hline Thermoanaerobacter ethanolicus ATCC $31550^{\mathrm{T}}$ & 28.3 & 4.4 & 0.8 & & & & & & & & & & \\
\hline Thermoanaerobacter thermohydrosulfuricus DSM $567^{\mathrm{T}}$ & 28.1 & 4.3 & 2.3 & 1.9 & & & & & & & & & \\
\hline Thermoanaerobacter kivuii DSM $2030^{\mathrm{T}}$ & 26.7 & 3.7 & 4.3 & 4.4 & 3.6 & & & & & & & & \\
\hline Thermoanaerobacter finnii DSM $3389^{\mathrm{T}}$ & 27.8 & 1.7 & 3.8 & 4.2 & 3.6 & 3.8 & & & & & & & \\
\hline Thermoanaerobacter sp. strain Gluc 1 & 26.9 & 0.9 & 3.0 & 3.4 & 3.3 & 3.0 & 0.8 & & & & & & \\
\hline Thermoanaerobacterium thermosaccharolyticum ATCC $7956^{\mathrm{T}}$ & 26.0 & 13.9 & 14.2 & 14.1 & 13.8 & 14.4 & 13.9 & 13.8 & 14.0 & 15.3 & & & \\
\hline Thermoanaerobacterium lactoethylicum ZE-1 & 26.0 & 14.1 & 13.7 & 13.6 & 13.3 & 14.2 & 14.1 & 13.8 & 14.1 & 15.3 & 2.4 & & \\
\hline Thermoanaerobacterium thermosulfurigenes ATCC $33743^{\mathrm{T}}$ & 26.3 & 14.1 & 13.6 & 13.5 & 13.2 & 14.3 & 13.9 & 13.8 & 13.9 & 15.5 & 2.1 & 1.0 & \\
\hline Thermoanaerobacterium xylanolyticum DSM $7097^{\mathrm{T}}$ & 26.3 & 14.4 & 13.8 & 13.5 & 13.2 & 14.2 & 14.2 & 14.0 & 14.2 & 15.8 & 2.5 & 1.5 & 1.0 \\
\hline
\end{tabular}

${ }^{a}$ See Materials and Methods. The sequences used in this analysis were obtained from the Ribosomal Database Project, version 4.0 (21). Only 1,320 unambiguous nucleotides were used.

98.4\%), as well as Thermoanaerobacter acetoethylicus, Thermoanaerobacter ethanolicus, and Thermoanaerobacter thermohydrosulfuricus (average level of similarity, 95.8\%). On the basis of its optimum growth temperature $\left(55\right.$ to $\left.60^{\circ} \mathrm{C}\right)$, which is the lowest optimum growth temperature among the Thermoanaerobacter strains that have been examined, and phenotypic characteristics, strain SEBR $5268^{\mathrm{T}}$ can be clearly differentiated from the seven previously validly described Thermoanaerobacter species $(9,22,32,35,39)$ (Table 3 ). Strain SEBR $5268^{\mathrm{T}}$ differs from $T$. brockii $(22,42)$ and $T$. ethanolicus $(39)$ by its higher DNA $\mathrm{G}+\mathrm{C}$ content. In contrast to our isolate, $T$. brockii does not use mannose and D-xylose, while $T$. ethanolicus does not use mannitol, whereas strain SEBR $5268^{\mathrm{T}}$ does. Recent studies revealed that $T$. ethanolicus and $T$. thermohydrosulfuricus are poor $\mathrm{H}_{2}$ users in the presence of thiosulfate compared

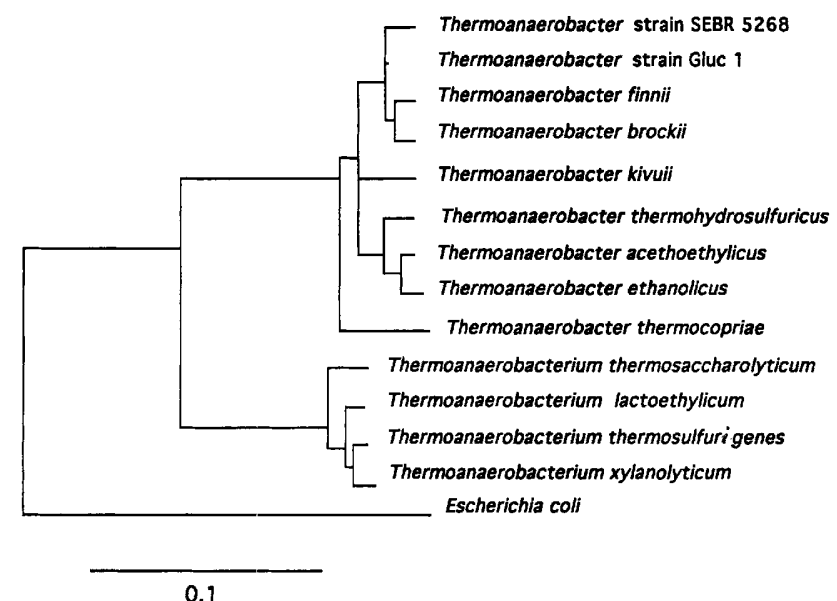

FIG. 3. Dendrogram showing the position of strain SEBR $5268^{\mathrm{T}}$ among representatives of the genus Thermoanaerobacter and related genera. The dendrogram was derived from the evolutionary distance matrix shown in Table 1. with strain SEBR $5268^{\mathrm{T}}$ (13). Strain SEBR $5268^{\mathrm{T}}$ is not related to $T$. acetoethylicus as the latter organism is a gram-negative nonsporulating bacterium that cannot produce lactate from fermentation of glucose $(2,32)$. Furthermore, T. acetoethylicus does not use pyruvate and D-xylose, whereas strain SEBR $5268^{\mathbf{T}}$ does. Although strain Gluc 1, a partially characterized isolate obtained from a 6,779-m-deep Swedish bore hole, is morphologically and phylogenetically similar to strain SEBR $5268^{\mathrm{T}}$, it produces ethanol, lactate, $\mathrm{CO}_{2}$, and $\mathrm{H}_{2}$ from fermentation of glucose (38), whereas strain SEBR $5268^{\mathrm{T}}$ produces acetate in addition to these products. The phenotypically most closely related Thermoanaerobacter species is T. finnii. However, strain SEBR $5268^{\mathrm{T}}$ differs from $T$. finnii in its optimum temperature and $\mathrm{pH}$ for growth and uses melibiose. Furthermore, when $T$. finnii is cultured under the same growth conditions as strain SEBR $5268^{\mathrm{T}}$, it produces ethanol as the major end product of glucose metabolism, whereas strain SEBR $5268^{\mathrm{T}}$ produces equal amounts of lactate and ethanol. However, it is possible that varying culture conditions may affect the end product profile, as has been reported for $T$. ethanolicus (39).

A comparison of the $16 \mathrm{~S}$ ribosomal DNA sequence of strain SEBR $5268^{\mathrm{T}}$ with the sequences of Thermoanaerobacter spe-

TABLE 2. Levels of DNA relatedness for T. brockii, $T$. finnii, and three new strains obtained from oil wells

\begin{tabular}{lccc}
\hline \multirow{2}{*}{$\begin{array}{c}\text { Source of } \\
\text { unlabelled DNA }\end{array}$} & \multicolumn{3}{c}{$\%$ Relatedness to ${ }^{3} \mathrm{H}$-labelled DNA from ${ }^{a}$ : } \\
\cline { 2 - 4 } & T. brockii & T. finnii & SEBR 5268 \\
\hline T. brockii & 100 & 97 & 76 \\
T. finnii & 89 & 100 & 85 \\
SEBR 5268 & 85 & 76 & 100 \\
SEBR 7311 & $96^{b}$ & 75 & $89^{b}$ \\
SEBR 7312 & 81 & 78 & 86 \\
\hline
\end{tabular}

${ }^{a}$ Unless indicated otherwise, the $\Delta T_{m}$ was $0^{\circ} \mathrm{C}$.

${ }^{b}$ The $\Delta T_{m}$ was $1^{\circ} \mathrm{C}$. 
TABLE 3. Salient features of Thermoanaerobacter species and subspecies

\begin{tabular}{|c|c|c|c|c|c|c|c|c|c|c|c|c|}
\hline \multirow{2}{*}{ Taxon } & \multirow{2}{*}{ Cell size $(\mu \mathrm{m})$} & \multirow{2}{*}{$\begin{array}{l}\text { Spore } \\
\text { formation }\end{array}$} & \multirow{2}{*}{$\begin{array}{l}\text { Gram } \\
\text { reaction }\end{array}$} & \multirow{2}{*}{ Flagellation } & \multirow{2}{*}{$\begin{array}{c}\mathrm{G}+\mathrm{C} \\
\text { content } \\
(\mathrm{mol} \%)\end{array}$} & \multicolumn{2}{|c|}{ Temp $\left({ }^{\circ} \mathrm{C}\right)$} & \multirow{2}{*}{$\begin{array}{l}\text { Optimum } \\
\mathrm{pH}\end{array}$} & \multicolumn{4}{|c|}{ Substrates used ${ }^{a}$} \\
\hline & & & & & & Range & Optimum & & Melibiose & Mannose & Xylose & Mannitol \\
\hline T. acetoethylicus & $1.5-2.5 \times 0.6$ & - & Negative & Peritrichous & 31 & $40-80$ & 65 & $\mathrm{NR}^{c}$ & NR & + & - & NR \\
\hline T. ethanolicus & $4-8 \times 0.3-0.8$ & - & Variable & Peritrichous & 32 & $37-78$ & 69 & $5.8-8.5$ & NR & + & + & - \\
\hline T. thermohydrosulfuricuse & $2-13 \times 0.3-0.6$ & + & Variable & Peritrichous & $35-37$ & $28-78$ & $67-69$ & $6.9-7.5$ & NR & + & + & \pm \\
\hline T. brockii subsp. brockil ${ }^{f}$ & $2-20 \times 0.8-1.0$ & + & Positive & NR & $30-31$ & $40-80$ & $65-70$ & 7.5 & NR & - & - & NR \\
\hline T. brockii subsp. finnii ${ }^{g}$ & $1-4 \times 0.4-0.6$ & + & Variable & NR & 32 & $40-75$ & 65 & $6.5-6.8$ & + & + & + & + \\
\hline $\begin{array}{l}\text { T. brockii subsp. } \\
\text { lactiethylicus }\end{array}$ & $2-3 \times 0.5^{i}$ & + & Positive & Peritrichous & 35 & $37-75$ & $55-60$ & 7.3 & - & + & + & + \\
\hline $\begin{array}{l}a+, \text { positive; }- \text {, negative } \\
{ }^{b} \text { Data from references } 2 \\
\text { " NR, not reported. } \\
{ }^{\circ} \text { Data from references } 2 \\
\text { "Data from reference } 22 \\
{ }^{f} \text { Data from references } 22 \\
{ }_{g} \text { Data from reference } 35 \\
{ }^{\prime} \text { Data from this study. } \\
{ }^{i} \text { Average cell dimensions }\end{array}$ & $\begin{array}{l} \pm \text {, variable. } \\
\text { and } 32 \text {. } \\
\text { and } 39 \text {. } \\
\text { and } 42 \text {. } \\
\text { during the ex }\end{array}$ & 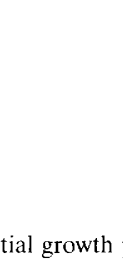 & . & & & & & & & & & \\
\hline
\end{tabular}

cies also revealed that strain SEBR $5268^{\mathrm{T}}$ is more closely related to T. brockii and T. finnii (level of similarity, 98.3\%) than to T. thermohydrosulfuricus (level of similarity, 95.7\%), T. ethanolicus (level of similarity, 95.6\%), Thermoanaerobacter kivui (level of similarity, 96.3\%), or Thermoanaerobacter thermocopriae (level of similarity, 94.7\%). It has been proposed that if the level of $16 \mathrm{~S}$ rRNA similarity is more than $97 \%$, it should not be used to distinguish taxonomically related strains (36), and therefore DNA-DNA hybridization experiments were performed. Our DNA-DNA hybridization data confirmed that strain SEBR $5268^{\mathrm{T}}$ could not be classified as a member of a new Thermoanaerobacter species. T. brockii and T. finnii are also closely related to each other (level of similarity, $98.9 \%$ ). On the basis of our DNA-DNA hybridization data, it is evident that these organisms should not be distinguished at the species level (Table 2). This is in contrast to the results of Schmid et al. (35), who obtained values low enough to place $T$. finnii and $T$. brockii strains in separate species. This discrepancy in results can be explained by the fact that two different methods were used for DNA-DNA hybridization experiments. The DNA-DNA hybridization method has been refined, and now the data include $\Delta T_{m}$ values for improved sensitivity; the $\Delta T_{m}$ should be $>5^{\circ} \mathrm{C}$ to differentiate species. The $\Delta T_{m}$ value obtained in most hybridization experiments performed with $T$. brockii, T. finnii, and strain SEBR $5268^{\mathrm{T}}$ was $0^{\circ} \mathrm{C}$; the only exception was the value obtained in the experiment performed with a $T$. brockii strain and strain SEBR $7311\left(\Delta T_{m}, 1^{\circ} \mathrm{C}\right)$, which indicated that these organisms should be considered strains rather than members of distinct species. DNA-DNA hybridization studies performed with two other oil field Thermoanaerobacter strains (SEBR 7311 and SEBR 7312) also gave similar results. On the basis of the results described above, we propose that $T$. finnii should be reclassified in the species $T$. brockii since the latter bacterium was described first (42). Therefore, $T$. finnii becomes a new subspecies of $T$. brockii, $T$. brockii subsp. finnii comb. nov. We also propose that strain SEBR $5268^{\mathrm{T}}$ should be classified as a member of a new subspecies of $T$. brockii, $T$. brockii subsp. lactiethylicus. The description of the genus Thermoanaerobacter is the description given previously by Lee et al. (22).

Our results also indicate that $T$. brockii strains are widely distributed in nature as they have now been isolated from soil, lake sediments, volcanic hot springs, and subsurface terrain, such as oil fields and deep bore holes. As these organisms are sporulators, their distribution in such a diverse range of ecosystems is perhaps not surprising.

Emendation of the species description of Thermoanaerobacter brockii Zeikus, Hegge, and Anderson 1979; Lee, Jain, Lee, Lowe, and Zeikus 1993. Thermoanaerobacter brockii (brock'i.i. M. L. gen. n. brockii, of Brock, named for Thomas Dale Brock, who performed pioneering studies on the physiological ecology of extreme thermophiles). Rods are 0.4 to 1.0 by 1 to $20 \mu \mathrm{m}$. Cells occur singly, in pairs, in short chains, and in filaments. Gram positive. Heat-resistant terminal endospores are formed. Colonies are circular and 0.2 to $4 \mathrm{~mm}$ in diameter. Thermophilic. The optimum growth temperature is 55 to $70^{\circ} \mathrm{C}$; the temperature range for growth is 35 to $85^{\circ} \mathrm{C}$. The optimum $\mathrm{pH}$ is 6.5 to 7.5 . Obligate anaerobe. Chemoorganotrophic. Ferments hexoses and pyruvate. The end products of glucose fermentation are ethanol, lactate, acetate, $\mathrm{H}_{2}$, and $\mathrm{CO}_{2}$. Reduces thiosulfate to hydrogen sulfide. The $\mathrm{G}+\mathrm{C}$ content of the DNA is 30 to 35 mol\%. Isolated from the sediment of lakes, hot springs, and oil wells.

Description of Thermoanaerobacter brockii subsp. brockii Zeikus, Hegge, and Anderson 1979; Lee, Jain, Lee, Lowe, and Zeikus 1993. Thermoanaerobacter brockii subsp. brockii (brock'i.i. M. L. gen. n. brockii, of Brock, named for Thomas Dale Brock, who performed pioneering studies on the physiological ecology of extreme thermophiles). Short rods are 1.0 by 2 to $20 \mu \mathrm{m}$. Cells frequently vary in length (minicells) and occur in pairs, chains, and filaments. Gram positive. Round, heat-resistant terminal endospores are formed. Cytochrome pigments and catalase are absent. Colonies are circular, 0.2 to $0.3 \mathrm{~mm}$ in diameter, flat, mucoid, and nonpigmented. Monolayer cell wall architecture without an outer wall membrane. Growth is inhibited by penicillin, cycloserine, streptomycin, tetracycline, and chloramphenicol. Thermophilic. The optimum growth temperature is 65 to $70^{\circ} \mathrm{C}$; the temperature range for growth is $>35$ to $<85^{\circ} \mathrm{C}$. The $\mathrm{pH}$ range for growth is 5.5 to 9.5 ; the optimum $\mathrm{pH}$ is 7.5 . Obligate anaerobe. Chemoorganotrophic. Ferments glucose, maltose, sucrose, lactose, cellobiose, starch, and pyruvate. Does not use xylose, cellulose, arabinose, mannose, lactate, tartrate, ethanol, tryptone, Casamino Acids, and pectin. The end products of glucose fermentation are ethanol, lactate, acetate, $\mathrm{H}_{2}$, and $\mathrm{CO}_{2}$. Reduces thiosulfate to hydrogen sulfide. The $\mathrm{G}+\mathrm{C}$ content of the DNA is 30 to $31 \mathrm{~mol} \%$. Isolated from a thermal spring sediment in Yellowstone National Park. 
The type strain is HTD4 (= DSM $1457=$ ATCC 33075).

Description of Thermoanaerobacter brockii subsp. finnii Schmid, Giesel, Schobert, and Sahm 1986. Thermoanaerobacter brockii subsp. finnii (fin'ni.i. M. L. gen. n. finnii, of Finn, named for Robert K. Finn, who made important contributions to the development of the ethanol vacuum fermentation process). Short rods are 0.4 to 0.6 by 1 to $4 \mu \mathrm{m}$. Cells occur singly, in pairs, and in short chains and are motile. Occasionally coccoid cells are found. Heat-resistant terminal endospores are formed. Colonies are circular, 1 to $3 \mathrm{~mm}$ in diameter, smooth, and white. Contains peptidoglycan of the meso-diaminopimelic acid type. Susceptible to penicillin $G$ and tetracycline. Thermophilic. The optimum growth temperature is $65^{\circ} \mathrm{C}$; the temperature range for growth is 40 to $75^{\circ} \mathrm{C}$. The optimum $\mathrm{pH}$ is 6.5 to 6.8. Obligate anaerobe. Chemoorganotrophic. Ferments glucose, fructose, galactose, mannose, cellobiose, maltose, sucrose, lactose, xylose, ribose, mannitol, and pyruvate. The end products of glucose and xylose fermentation are ethanol and $\mathrm{CO}_{2}$, as well as minor amounts of L-lactate and acetate. Reduces thiosulfate to hydrogen sulfide. The $\mathrm{G}+\mathrm{C}$ content of the DNA is $32 \mathrm{~mol} \%$. Isolated from sediment sludge from Lake Kivu in East Africa.

The type strain is AKO-1 (= DSM 3389).

Description of Thermoanaerobacter brockii subsp. lactiethylicus subsp. nov. Thermoanaerobacter brockii subsp. lactiethylicus (lac. ti. e. thy' li. cus. L. n. lacticum, lactic acid; M. L. n. ethylicus, ethyl alcohol; lactiethylicus, referring to the production of both lactic acid and ethanol). Cells are straight rods $(0.5$ by $2 \mu \mathrm{m}$ ) that are motile by means of peritrichous flagella and occur singly or in pairs in young cultures. Pleomorphic filamentous cells (length, $15 \mu \mathrm{m}$ ) occur in old cultures. Gram positive. Spores are formed in medium containing D-xylose as an electron donor and thiosulfate as an electron acceptor. Colonies in roll tubes are $4 \mathrm{~mm}$ in diameter after 2 days of incubation at $60^{\circ} \mathrm{C}$, smooth, uniformly round, mucoid, nonpigmented, and flat. The optimum temperature is 55 to $60^{\circ} \mathrm{C}$ (range, 40 to $75^{\circ} \mathrm{C}$ ). Tolerates up to $4 \% \mathrm{NaCl}$. The optimum sodium chloride concentration for growth is $1 \%$. Obligately anaerobic. Ferments glucose, fructose, galactose, mannose, Dribose, D-xylose, cellobiose, lactose, maltose, sucrose, mannitol, and pyruvate. The fermentation products from glucose are lactate, acetate, ethanol, $\mathrm{H}_{2}$, and $\mathrm{CO}_{2}$. Reduces thiosulfate to hydrogen sulfide. The $\mathrm{G}+\mathrm{C}$ content of the DNA is $35 \mathrm{~mol} \%$. Phylogenetically related to Thermoanaerobacter species in the low-G+C-content subbranch of the gram-positive bacteria. The habitat is geothermal oil samples.

The type strain is SEBR 5268 (= DSM 9801).

\section{ACKNOWLEDGMENTS}

This study was supported by a grant from Elf Aquitaine (to J.-L.C.) and in part by a grant from the Australian Research Council (to B.K.C.P.).

We are indebted to K. D. Jahnke, Deutsche Sammlung von Mikroorganismen, Braunschweig, Germany, for determining the DNA base composition and to $\mathrm{S}$. Chaillou for technical assistance.

\section{REFERENCES}

1. Balch, W. E., G. E. Fox, L. J. Magrum, C. R. Woese, and R. S. Wolfe. 1979. Methanogens: reevaluation of a unique biological group. Microbiol. Rev. 43:260-296

2. Ben-Bassat, A., and J. G. Zeikus. 1981. Thermobacteroides acetoethylicus gen. nov. and spec. nov., a new chemoorganotrophic, anaerobic, thermophilic bacterium. Arch. Microbiol. 128:365-370.

3. Bernard, F. P., J. Connan, and M. Magot. 1992. Indigenous microorganisms in connate water of many oil fields: a new tool in exploration and production techniques, paper SPE 24811,p. 467-476. In Proceedings of the 67th Annual Technical Conference and Exhibition of the Society of Petroleum Engineers. Society of Petroleum Engineers, Richardson, Tex.
4. Brenner, D. J. 1978. Characterization and clinical identification of Enterobacteriaceae by DNA hybridization. Prog. Clin. Pathol. 7:71-117.

5. Brenner, D. J., A. C. McWhorter, J. K. Leete-Knudson, and A. G. Steigerwalt. 1982. Escherichia vulneris: a new species of Enterobacteriaceae associated with human wounds. J. Clin. Microbiol. 15:1133-1140.

6. Cashion, P., M. A. Holder-Franklin, J. McCully, and M. Franklin. 1977. A rapid method for the base ratio determination of bacterial DNA. Anal. Biochem. 81:461-466.

7. Cayol, J.-L., B. Ollivier, B. K. C. Patel, G. Prensier, J. Guezennec, and J.-L. Garcia. 1994. Isolation and characterization of Halothermothrix orenii gen. nov., sp. nov., a halophilic, thermophilic, fermentative, strictly anaerobic bacterium. Int. J. Syst. Bacteriol. 44:534-540.

8. Cochrane, W. J., P. S. Jones, P. F. Sanders, D. M. Holt, and M. J. Mosiey. 1988. Studies on the thermophilic sulfate-reducing bacteria from a souring North Sea oil field, p. 301-316. In Proceedings of the Society of Petroleum Engineers European Conference. Society of Petroleum Engineers, Richardson, Tex.

9. Collins, M. D., P. A. Lawson, A. Willems, J. J. Cordoba, J. FernandezGarayzabal, P. Garcia, J. Cai, H. Hippe, and J. A. E. Farrow. 1994. The phylogeny of the genus Clostridium: proposal of five new genera and eleven new species combinations. Int. J. Syst. Bacteriol. 44:812-826.

10. Crosa, J. H., D. J. Brenner, and S. Falkow. 1973. Use of a single-strandspecific nuclease for analysis of bacterial and plasmid deoxyribonucleic acid homo- and heteroduplexes. J. Bacteriol. 115:904-911.

11. Davydova-Charakhch'yan, I. A., V. G. Kuznetsova, L. L. Mityushina, and S. S. Belayaev. 1992. Methane-forming bacilli from oil fields of Tataria and Western Siberia. Mikrobiologiya 61:299-305.

12. Fardeau, M.-L., J.-L. Cayol, M. Magot, and B. Ollivier. 1993. H oxidation in the presence of thiosulfate, by a Thermoanaerobacter strain isolated from an oil-producing well. FEMS Microbiol. Lett. 113:327-332.

13. Fardeau, M.-L., J.-L. Cayol, M. Magot, and B. Ollivier. 1993. Hydrogen oxidation abilities in the presence of thiosulfate as electron acceptor within the genus Thermoanaerobacter. Curr. Microbiol. 29:269-272.

14. Faudon, C., M.-L. Fardeau, J. Heim, B. K. C. Patel, M. Magot, and B. Ollivier. 1995. Peptide and amino acid oxidation in the presence of thiosulfate by members of the genus Thermoanaerobacter. Curr. Microbiol 30:1-6.

15. Felsentein, J. 1993. PHYLIP (phylogenetic inference package), version 3.51c. Department of Genetics, University of Washington, Seattle.

16. Grimont, P. A. D., M. Y. Popoff, F. Grimont, C. Coynault, and M. Lemelin. 1980. Reproductibility and correlation study of three deoxyribonucleic acid hybridization procedures. Curr. Microbiol. 4:325-330.

17. Hungate, R. E. 1969. A roll tube method for cultivation of strict anaerobes Methods Microbiol. 3B:117-132.

18. Jain, M. K., T. E. Thompson, E. Conway de Macario, and J. G. Zeikus. 1987 Speciation of Methanobacterium strain Ivanov, as Methanobacterium ivanovii, sp. nov. Syst. Appl. Microbiol. 9:77-82.

19. Jukes, T. H., and C. R. Cantor. 1969. Evolution of protein molecules, p. 21-132. In H. N. Munro (ed.), Mammalian protein metabolism. Academic Press, New York.

20. Kumar, S., K. Tamura, and M. Nei. 1993. MEGA: Molecular Evolutionary Genetic Analysis, version 1.0. The Pennsylvania State University, University Park.

21. Larsen, N., G. J. OIsen, B. L. Maidak, M. J. McCaughey, R. Overbeek, T. J. Macke, T. L. Marsh, and C. R. Woese. 1993. The Ribosomal Database Project. Nucleic Acids Res. 21(Suppl.):3021-3023.

22. Lee, Y. E., M. K. Jain, C. Lee, S. E. Lowe, and J. G. Zeikus. 1993. Taxonomic distinction of saccharolytic thermophilic anaerobes: description of Thermoanaerobacterium xylanolyticum gen. nov., sp. nov., and Thermoanaerobacterium saccharolyticum gen. nov., sp. nov.; reclassification of Thermoanaerobium brockii, Clostridium thermosulfurogenes, and Clostridium thermohydrosulfuricum E100-69 as Thermoanaerobacter brockii comb. nov., Thermoanaerobacterium thermosulfurigenes comb. nov., and Thermoanaerobacter thermohydrosulfuricus comb. nov., respectively; and transfer of Clostridium thermohydrosulfuricum $39 \mathrm{E}$ to Thermoanaerobacter ethanolicus. Int. J. Syst. Bacteriol. 43:41-51.

23. Love, C. A., B. K. C. Patel, P. D. Nichols, and E. Stackebrandt. 1993 Desulfotomaculum australicum, sp. nov., a thermophilic sulfate-reducing bacterium isolated from the Great Artesian Basin of Australia. Syst. Appl. Microbiol. 16:244-251.

24. Lowe, S. E., M. K. Jain, and J. G. Zeikus. 1993. Biology, ecology, and biotechnological applications of anaerobic bacteria adapted to environmental stresses in temperature, $\mathrm{pH}$, salinity, or substrates. Microbiol. Rev. 57: 451-509.

25. Macy, J. M., J. E. Snellen, and R. E. Hungate. 1972. Use of syringe methods for anaerobiosis. Am. J. Clin. Nutr. 25:1318-1323.

26. Meshbah, M., U. Premachandran, and W. Whitman. 1989. Precise measurement of the $\mathrm{G}+\mathrm{C}$ content of deoxyribonucleic acid by high-performance liquid chromatography. Int. J. Syst. Bacteriol. 39:159-167.

27. Miller, T. L., and M. J. Wollin. 1974. A serum modification of the Hungate technique for cultivating obligate anaerobes. Appl. Microbiol 27:985-987.

28. Nazina, T. N., and E. P. Rozanova. 1978. Thermophilic sulfate-reducing bacteria from oil strata. Mikrobiologiya 47:142-148. 
29. Ng, T. K., P. J. Weimer, and L. J. Gawel. 1989. Possible nonanthropogenic origin of two methanogenic isolates from oil-producing wells in the San Miguelito field, Ventura County, California. Geomicrobiol. J. 7:185-192.

30. Pedersen, K. 1993. The deep subterranean biosphere. Earth Sci. Rev. 34: 243-260.

31. Pfennig, N., F. Widdel, and H. G. Trüper. 1981. The dissimilatory sulfatereducing bacteria, p. 926-940. In M. P. Starr, H. Stolp, H. G. Truper, A. Balows, and H. G. Schlegel (ed.), The prokaryotes, vol. 1. Springer-Verlag, Berlin.

32. Rainey, F. A., and E. Stackebrandt. 1993. Transfer of the type species of the genus Thermobacteroides to the genus Thermoanaerobacter as Thermoanaerobacter acetoethylicus (Ben-Bassat and Zeikus 1981) comb. nov., description of Coprothermobacter gen. nov., and reclassification of Thermobacteroides proteolyticus as Coprothermobacter proteolyticus (Ollivier et al. 1985) comb. nov. Int. J. Syst. Bacteriol. 43:857-859.

33. Ravot, G., M. Magot, M.-L. Fardeau, B. K. C. Patel, G. Prensier, A. Egan, J.-L. Garcia, and B. Ollivier. 1995. Thermotoga elfii sp. nov., a novel thermophilic bacterium from an African oil-producing well. Int. J. Syst. Bacteriol. 45:308-314.

34. Redburn, A. C., and B. K. C. Patel. 1993. Phylogenetic analysis of Desulfotomaculum thermobenzoicum using polymerase chain reaction-amplified $16 \mathrm{~S}$ rRNA-specific DNA. FEMS Microbiol. Lett. 113:81-86.

35. Schmid, U., H. Giesel, S. M. Schoberth, and H. Sahm. 1986. Thermoanaer- obacter finnii spec. nov., a new ethanologenic sporogenous bacterium. Syst. Appl. Microbiol. 8:80-85.

36. Stackebrandt, E., and B. M. Goebel. 1994. Taxonomic note: a place for DNA-DNA reassociation and 16S rRNA sequence analysis in the present species definition in bacteriology. Int. J. Syst. Bacteriol. 44:846-849.

37. Stetter, K. O., R. Huber, E. Blochl, M. Kurr, R. D. Eden, M. Fielder, H. Cash, and I. Vance. 1993. Hyperthermophilic Archaea are thriving in deep North Sea and Alaskan reservoirs. Nature (London) 365:743-745.

38. Szewzyk, U., R. Szewzyk, and T. A. Stenstrom. 1994. Thermophilic, anaerobic bacteria isolated from a deep borehole in granite in Sweden. Proc. Natl. Acad. Sci. USA 91:1810-1813.

39. Wiegel, J., and L. G. Ljungdahl. 1981. Thermoanaerobacter ethanolicus gen. nov., spec. nov., a new extreme thermophilic, anaerobic bacterium. Arch. Microbiol. 128:343-348.

40. Winker, S., and C. R. Woese. 1991. A definition of the domains Archaea Bacteria and Eucarya in terms of small subunit ribosomal RNA characterisBacteria and Eucarya in terms of small
tics. Syst. Appl. Microbiol. 13:161-165.

41. Winter, J., and G. Zellner. 1990. Thermophilic anaerobic degradation of carbohydrates: metabolic properties of microorganisms from the different phases. FEMS Microbiol. Rev. 75:139-154.

42. Zeikus, J. G., P. W. Hegge, and M. A. Anderson. 1979. Thermoanaerobium brockii gen. nov. and sp. nov., a new chemoorganotrophic, caldoactive, anaerobic bacterium. Arch. Microbiol. 122:41-48. 